\title{
GIOVANNI SEBENICO
}

\section{(Prispevek k biografiji)}

Miloš M. Ve li mirović

$\mathrm{V}$ italijanskih in agleških glasbenozgodovinskih virih iz druge polovice sedemnajstega stoletja srečujemo ime Giovanni Sebenico, ki se omenja kot zelo dober tenorist, kot orglavec, »maestro di capellac in končno kot skladatelj dveh oper. Ker je Sebenico živel določen čas v Benetkah in ker so najstarejši poznani podatki o njem iz tega mesta, so seveda vsi poznejši leksikografi mislili, da gre pač za skladatelja, ki je rojen v Benetkah. Vendar pa, kot se bo še nadalje pokazalo, pojma »Benetke« ni jemati ozko in tako ni treba misliti, da se nanaša na mesto tega imena. Tolmačiti ga je kot izraz, ki vključuje celo področje, in to tako današnje pokrajine tega imena kot ozemlje, ki je $v$ tistem času bilo pod oblastjo Beneške republike.

Znano je dejstvo, da so bili posamezni umetniki $v$ času renesanse poznani po imenu mesta, $v$ katerem so se rodili. Za ilustracijo take prakse lahko navedemo primer Palestrine ali pa Istrijanca Francesca Laurane. Očitno je torej, če vemo, da je italijansko ime za mesto Šibenik vedno bilo Sebenico, da obstaja logična možnost, da gre $v$ primeru tega skladatelja lahko za človeka, ki bi bil po rodu iz Šibenika. Morda bi bil to celo neki Dalmatinec, ki se je italianiziral, kar se je tudi dogajalo v preteklih stoletjih. Toda treba je podčrtati že na začetku, da ni na razpolago niti enega dokumenta, ki bi podkrepil to domnevo. Namen te razprave je, da razišče do sedaj pristopne podatke o skladatelju z imenom Giovanni Sebenico in postavi vprašanje o njegovem poreklu. Že samo ime )Sebenicoc je dovolj, da vzbudi med jugoslovanskimi muzikologi zanimanje za skladatelja, ki nosi to ime. To pa je bila tudi vzpodbuda za raziskovanja, ki so pripeljala do naslednjih rezultatov.

$\mathrm{V}$ glasbenih leksikonih in enciklopedijah, ki so navajali maloštevilne podatke o Giovanniju Sebenicu, vlada negotovost, kdaj se je rodil. Navadno se navaja, da je rojen $\mathrm{v}$ Benetkah okrog leta $1650 .{ }^{1} \mathrm{Na}$ podlagi nedavno objavljenega podatka pa se zdi, da bi bilo treba to domnevo popraviti in odslej soditi, da je bil Sebenico najbrž rojen okrog leta 1640, če že ne prej. Vzrok temu je, da je bil Giovanni Sebenico 14. avgusta 1660 imenovan na položaj »vice maestra« pri glasbeni kapeli katedrale 
v mestu Cividale nel Friuli (Čedad), vzhodno od Vidma in nedaleč od Gorice. Na osnovi ohranjenih dokumentov o tej nastavitvi se ve, da je pri tem od 31 odbornikov 25 glasovalo zanj, medtem ko je bilo šest glasov proti. ${ }^{2}$

Kar se tiče kraja, v katerem se je Sebenico rodil, navajajo dokumenti v Čedadu znatno pozneje, da mu je bila ponudena služba v kraju Corbolo, ki se omenja kot »la sua patria (. ${ }^{3}$ Edino naselje z imenom Corbolo, ki nam ga je uspelo najti, je majhna vas $v$ delti reke Pad, okrog $35 \mathrm{~km}$ vzhodno od mesta Rovigo, južno od Adrie. ${ }^{4}$ Vendar pa je $\mathrm{v}$ beneških dokumentih zanj rečeno, da je rojen $v$ Corbolone, kar je ime enega dela mesteca Santo Stino di Livenza nedaleč od mesta Portogruaro v Furlaniji. ${ }^{5}$ Ker sta obe omenjeni naselji spadali v teritorij Beneške republike, nam ti podatki $v$ vsakem primeru potrjujejo dejstvo, da je bil Sebenico po poreklu podložnik Benetk. Če pa zdaj upoštevamo že omenjeni običaj, da so posamezni umetniki nosili imena svojih rojstnih krajev, nastane vprašanje, od kod bi se znašel človek $\mathrm{z}$ imenom Sebenico $\mathrm{v}$ okolici Benetk. Sredi sedemnajstega stoletja so se Benečani bojevali s Turki in v času Kandijske vojne je bil Šibenik izpostavljen turškim napadom, medtem ko so Benečani branili mesto. ${ }^{6}$ Tako je možno, da je neka od ogroženih družin iz Šibenika zapustila svojo domačijo in odšla v kraje, ki so bili varnejši in bolj oddaljeni od neposredne nevarnosti.

Toda dejstvo, da so najbrž nekatere družine zapustile Šibenik, še nujno ne pomeni, da so to bile družine slovanskega porekla, ker je prav tako lahko prišlo do umika italijanskih družin, ki so tedaj živele $\mathrm{v}$ mestu in so se po krajšem bivanju (poslovnega ali kakšnega drugega značaja) zopet vrnile $v$ Italijo. Zanimivo je tudi omeniti, da je trdnjava $v$ Sibeniku, okoli katere so bile bitke, poznana pod imenom sv. Ivana. Na podlagi tega se nam zdi mogoče postaviti hipotezo, da je Ivan (t. j. Giovanni) lahko bil rojen $\mathrm{v}$ Sibeniku in da je njegova rodbina verjetno okrog 1. 1647-1648 zaradi vojnih neprilik prešla na beneško ozemlje z otrokom, ki je moral biti tedaj star okrog deset let. Poudarimo naj, da je to le domneva, vendar za nas zelo privlačna domneva, ki nas je tudi vzpodbudila $k$ temu delu. Glede na doslej dostopne podatke se ne ve nič zanesljivega o glasbenem šolanju tega glasbenika. Caffi, eden od zgodovinarjev glasbenega življenja Benetk, navaja, da je bil Sebenico učenec znanega italijanskega skladatelja Legrenzija, in opirajoč se na Caffija, navajajo leksikoni to informacijo kot tradicijo. ${ }^{7}$ Ker je bil Legrenzi poznan kot znamenit orglavec, in ker imamo podatke, da je tudi Sebenico dobro igral orgle, je verjetno ta domneva opravičena. Razen tega tudi ne smemo pozabiti, da je Legrenzi bival v Ferari med 1. 1657 in 1665 (mimogrede povedano, blizu kraja Corbola!) in da je treba, kot se zdi, možnost študija pri Legrenziju omejiti na čas pred letom 1660, ko je Sebenico dobil službo $v$ Čedadu, katera je najbrž zahtevala njegovo prisotnost $v$ tem mestu vsaj določen čas. Medtem ko imamo za to zgodnje razdobje njegovega življenja le pičle podatke, pa so podatki od leta 1663 dalje dostopni za vsako leto vse do njegove smrti leta 1705 .

Dne 29. julija 1663 je bil Sebenico sprejet kot tenorist $v$ kapelo cerkve sv. Marka v Benetkah s plačo sedemdeset dukatov, potem ko je 
bil na konkurzu boljši kot še dva kandidata za to mesto. ${ }^{8} \mathrm{~V}$ Benetkah se je Sebenico mudil najmanj dve, če ne kar dve in pol leti, do februarja 1666. ${ }^{9}$ Od prvega aprila 1666 pa se nahaja v Londonu kot pevec na dvoru angleškega kralja Karla II. ${ }^{10}$ Kako je prišlo do tega, da je Sebenico odšel $v$ Anglijo ni povsem ljasno. Toda ker je bila 1 . 1665 odposlana na kontinent neka misija, ki sta jo sestavljala dva glasbenika, ${ }^{10 a}$ da dobi pevce za službo na angleškem dvoru, ni izključeno, da so ti glasbeniki prišli $v$ Benetke in tam ponudili Sebenicu spremembo službe in da je ta potem izkoristil prvo priliko za odhod iz Benetk.

O življenju tako italijanskih kot angleških glasbenikov na dvoru Karla II. je precej obsežno dokumentarno gradivo, v katerem gre v večini primerov za zahteve za izplačilo zaostalih hononarjev, ki so bili tudi po nekaj let $\mathrm{v}$ zaostanku. ${ }^{11}$ Ker je ta vladar hotel posnemati način življenja, ki ga je videl na dvoru Ludvika XIV, kjer je v tem času deloval Lully, je bilo tudi na angleškem dvoru nekaj skupin glasbenikov. Tako je bila poleg »kraljevih muzikov ( tudi skupina )italijanskih muzikov«, nekateri glasbeniki pa so morali igrati tudi v privatni rimskokatoliški kapeli kraljice Katarine iz portugalske hiše Braganza.

Ohranjeni podatki kažejo, da je Sebenico pripadal »italijanskim muzikom « in da je po dveletnem bivanju zaprosil, da ga postavijo za kapelnika te skupine, kar priča, da ni bil samo pevec. Tej prošnji so ustregli in dne 29. aprila 1668 je dobil akt o nastavitvi $z$ naslovom )Master of the Italian Music(. ${ }^{12}$ Da se je Sebenico odlikoval kot pevec s svojim glasom, izpričuje poznani dnevnik Samuela Pepysa, ki je zapisal 28. septembra 1668 leta, da je slišal v času svojega obiska pri kraljici »italijansko kapelo«, ki je priplula v čolnu pod kraljičino okno in muzicirala celo uro in da se je med glasbeniki odlikoval kot pevec mseignor Joanniœ, kar je gotovo popačeno ime za Giovanni. ${ }^{13}$

Položaj kapelnika, kot je videti, je prehajal od enega muzika na drugega, kajti leta 1669 se omenja na tem mestu že nekdo drug. Toda leta 1670 je Sebenico zopet dobil dekret o nastavitvi kot mitalijanski muzik « v kraljevi privatni kapeli. ${ }^{14}$ Istega leta, 28. oktobra, mu je bil izdan potni list za Italijo, kamor je potoval po neimenovanem opravku. ${ }^{15}$ Ne vemo, koliko časa je bil na poti. Zadnji podatki o njegovem bivanju v Angliji so iz leta 1673. Prvega julija tega leta je bil izdan nalog, da se izdela zlato verižico in zlato medaljo $v$ vrednosti okrog 70 funtov šterlingov in da se oba predmeta izroči kot dar angleškega kralja njegovemu muziku Sebenicu. ${ }^{16}$ Ob pomanjkanju konkretnejših podatkov o njegovem muziciranju pokaže dejstvo, da dobiva tako dragocene darove, kako visok ugled je užival na angleškem dvoru. Pet dni pozneje mu je bil izdan potni list za povratek $\mathrm{v}$ Italijo, kamor se je želel vrniti. ${ }^{17} \mathrm{Zdi}$ se, da se po njegovem odhodu skupina italijanskih glasbenikov ni mogla več obdržati dolgo časa, kajti že 10. septembra istega leta je bil izdan kolektivni potni list »iz kateregakoli angleškega pristanišča za katerokoli francosko pristanišče. ${ }^{18}$

Za časa svojega bivanja $v$ Angliji je Sebenico tudi igral na orgle $\mathrm{v}$ kapeli angleške kraljice Katarine, o čemer najdemo podatke $\mathrm{v}$ memoarih Rogerja Northa. Iz le-teh je tudi razvidno, da je Sebenico igral 
na velike orgle, medtem ko je sicer znani angleški skladatelj Matthew Locke igral pri bogoslužju na manjše komorne orgle (pozitiv). ${ }^{19}$ Po nekaterih navedbah (katere pa pisec ni imel prilike preveriti), naj bi se nahajali rokopisi nekaterih Sebenicovih kompozicij iz tega časa $v$ biblioteki glasbene šole $\mathrm{v}$ Oxfordu. ${ }^{20}$ Glede na doslej objavljene biografske podatke moremo reči, da so leksikografi $v$ glavnem le vedeli, da je Sebenico bival $v$ Benetkah in Londonu, medtem ko je bilo naslednje obdobje njegovega življenja nezadostno raziskano, kar je vzbujalo vtis vrzeli. Vise, kar je bilo poznanega, je to, da se je v 80-ih letih 17. stoletja mudil $v$ Turinu in da je pozneje prešel $v$ Cividale nel Friuli. ${ }^{21}$ Medtem ko je to $v$ glavnem točno, so posameznosti manjkale, ker še ni bilo uporabljeno arhivsko gradivo za osvetlitev njegovega življenja. Toda arhivskega gradiva je v izobilju, tako da je danes mogoče rekonstruirati več ali manj neprekinjeno celoten potek Sebenicovega življenja in dela, potem ko je zapustil Anglijo.

Po povratku v Italijo Sebenicu ni bilo treba čakati na službo, ker se je takoj zaposlil kot »maestro di capellac na savojskem dvoru v Turinu. C̆e beremo najzgodnejši poznani arhivski podatek o njegovem bivanju v Turinu, dobimo dejansko vtis, da je stopil v službo še pred odhodom iz Londona. V knjigi izdatkov kraljeve hiše za leto 1673 (Conti Real Casa, vol. anno 1673, fol. $36 \mathrm{v}$, pod številko 164) se omenja izplačilo honorarja za zadnje tri četrtine leta 1673 , ki se imenuje kot letna plača v višini 2250 lir. Na podlagi tega podatka se vidi, da je 19. septembra tega leta to izplačilo odobreno za drugi in tretji kvartal in da je Sebenico podpisal priznanico 4. oktobra, medtem ko je za četrti kvartal prejel plačo in podpisal priznanico 4. januarja leta 1674.

Faksimile originalnega zapisa je tu priložen kot Fotografija št. $I^{22}$ Če za predhodno razdobje ni gotovih podatkov, da je Sebenico komponiral in da so bila njegova dela izvedena, pa je $\mathrm{v}$ Turinu očitno izkoristil prvo priliko, da pokaže svoje sposobnosti. Tako je bilo že 6. decembra 1673 izvedeno njegovo delo »L'Atalantac, ki je bilo verjetno $v$ stilu tedaj popularnih oper, ${ }^{23} \mathrm{v}$ katerih se je izkazovalo mnogo več pozornosti scenskim trikom in tehniki za realizacijo le-teh kot pa visoki glasbeni kvaliteti. Sebenico je bival v Turinu od 1673 do 1690, ko se njegovo ime stalno nahaja na seznamu plač glasbenikov na savojskem dvoru. ${ }^{24} \mathrm{~V}$ teku dveh naslednjih let, 1674 in 1675 , je prejel tudi posebni denarni nagradi, in to 300 lir dne 4 . marca 1674 in 725 lir dne 24. decembra $1675 .^{25}$

Ob prihodu v Turin je Sebenico stopil v službo savojskega vladarja Carla Emanuela, ki je umrl leta 1675 in ki ga je nasledil mladoletni sin Vittorio Amadeo II, v čigar imenu je vladala kot regentinja njegova mati Jeanne Baptiste de Nemours, po poreklu Francozinja ${ }^{26}$ ki je odobrila izplačilo denarnega daru $\mathrm{v}$ decembru leta 1675. Leto dni pozneje, 12. decembra 1676 , pa je regentinja naročila dva diamantna prstana, od katerih je enega namenila za svojega mmaestra di capellac Sebenica. Vendar se razvidi iz obrobne zabeležke poleg zapisa o izdatku za nabavo teh prstanov, da je Sebenico raje prejel denarno odškodnino v višini 500 
lir, njemu namenjeni prstan pa so vrnili juvelirju. ${ }^{27}$ Faksimile tega zapisa je priložen temu članku kot Fotografija št. II.

Pritožbe o dohodkih, ki niso dovolj veliki, da krijejo izdatke zaradi draginje, ne predstavljajo novost $\mathrm{v}$ biografijah poklicnih glasbenikov. In tako je tudi Sebenico naslovil prošnjo za povišanje plače svojemu delodajalcu, regentinji, v francoščini. ${ }^{28} \mathrm{Ni}$ vzroka, da bi dvomili, da je pred nami originalen dokument $\mathrm{z}$ njegovim lastnoročnim podpisom, ki je reproduciran na Fotografiji št. III. Frazeologija dokumenta je tipična za tedanji čas in celotni tekst te prošnje se glasi:

\section{Madame,}

Un serviteur passionè pour le service du Prince seroit trop heureux dans l'honneur qu'il à de le rendre, si la seule gloire de servir pouvoit fournir à sà necesitè. Je ne crois pas que pour tesmoigner ma passion respectueuse pour cette Royale Maison il soit besoin d'autre preuve apres mon assiduitè, et application passèes, que celle d'avoir preferè 500 Ducatons, que j'ay en cette Cour à 1200 , que j'avois en celle de S. M. Britannique. Il m'est trop sensible de voir que cet appointement n'est pas suffisant à mon besoin, n'y me peut permettre de prevenir la necessitè dans la quelle, et le temps, et les accidans me peuvent jetter en mettant quelque chose à part pour y pourvoir, affin que V. A. R. ne creut pas que l'interest prevalut à la gloire, que je fais de la servir. Je serois indigne des graces que j'ay receues de V. A. R. se je ne considerois que mon seul adventage, et je meriterois aussy d'estre le plus malheureux homme du monde si sans faire reflection de le pouvoir devenir je ne songeois de me mettre en estat de me secourrir. Le peu de reputation que j'ay dans le monde m’à presentè plusieurs occasions de grande fortune en divers endroits. $\mathrm{Si}$ V. A. R. croit que je puisse meriter celle de quelque mediocre adventage aupres d'elle, je suis prest de rennoncer à toutes les autres, quand mesme elles seroit immenses. Si non je la supplie tres humblement de me permettre que $j^{\prime}$ en proffitte; et de m'accorder la grace, que si je ne part pas de ses estat riche de fortune, je parte riche de l'honneur de ses bonnes graces, et suis avec tres profond respect -

Madame

de Votre Altesse Royale

Tres humble, tres obeissant et très fidelles serviteur

Giovanni Sebenico

Ker nam trenutno niso dostopni ostali arhivski podatki o njegovih dohodkih $v$ času službovanja v Turinu, ni mogoče presoditi, ali je Sebenico s svojo prošnjo uspel. Toda dejstvo, da je Sebenico ostal v Turinu še polnih trinajst let, govori za to, ali da je bilo njegovi zahtevi ustreženo ali pa (če je dovoljena taka domneva) da so mu pokazali, naj svojih sposobnosti $\mathrm{v}$ primerjavi z drugimi glasbeniki ne precenjuje. Kot »maestro di capellac je Sebenico $v$ Turinu razpolagal $s$ precej veliko skupino glasbenikov in to $\mathrm{s} 14$ pevci in 23 instrumentalisti. ${ }^{29}$ Ceprav lahko mislimo, da je $\mathrm{v}$ tako ugodnih pogojih imel priliko razviti svojo skladateljsko kot koncertno dejavnost, pa še ne moremo $\mathrm{z}$ gotovostjo ugotoviti, kam je usmeril svoja prizadevanja. Zato bi bilo koristno zavoljo ugotovitve obsega in vrste njegovega ustvarjalnega dela, da se ob 
priliki pregleda dokumente $\mathrm{v}$ turinskih arhivih in poizve, če je tam ostalo kakšno njegovo delo $v$ rokopisu, saj nam ni znano, da bi bile njegove kompozicije objavljene. ${ }^{30}$

Kar pa se tiče dohodkov v teku naslednjih let Sebenicovega bivanja $\mathbf{v}$ Turinu, je zanimivo omeniti, da je bila $v$ tem mestu $v$ predpustu leta 1681 izvedena opera »Lisimaco (, za katero je napisal libreto Christophor Ivanović iz Budve, ki je bil $\mathrm{v}$ tem času duhovnik v cerkvi sv. Marka $\mathrm{v}$ Benetkah. ${ }^{31}$ Vendar pa ni podatkov, na podlagi katerih bi mogli domnevati, da sta se Sebenico in Ivanović mogla ob tej priložnosti sestati.

Edini dokumentirani podatki iz tega časa se nanašajo na leto 1689 , ko je Sebenico poleg svoje plače prejel potnino za potovanje $v$ Nico. ${ }^{32}$ Istega leta $v$ predpustu pa je bila izvedena $v$ Turinu njegova opera »Leonida in Sparta ( Za zdaj ni mogoče podkrepiti domnevo, da je bilo to delo izvedeno že enkrat poprej, leta $1687 . .^{33}$ Medtem ko je partitura te opere najbrž izgubljena, sta se ohranila dva primerka libreta, od katerih se danes nahaja eden $\mathrm{v}$ Bologni in drugi $\mathrm{v}$ Washingtonu. ${ }^{34}$

V letu 1691 za Sebenica ni podatkov, spomladi leta 1692 pa je izvedena $\mathrm{v}$ beneškem gledališču SS. Giovanni e Paolo njegova opera L'opresso solevato. En primerek libreta za to opero je ohranjen $v$ Bologni. ${ }^{35}$ Zanimivo je pripomniti, da je Sebenico posvetil to opero "all'Altezza Serenissima del Duca Giorgio di Zell, Bronsvich, Lonembourghe, etcc ${ }^{36}$ Za zdaj bi bilo zelo težko ugotoviti, kako in zakaj je posvetil Sebenico to svoje delo severno nemškemu vojvodi iz rodbine, ki je vladala $\mathrm{v}$ mestu Celle, $\mathrm{s}$ katerim je bilo pozneje povezanih nekoliko dogodkov iz Bachovega in Haendlovega življenja. Znano pa je, da so Benečani dvakrat najeli čete tega vojvode za borbe proti Turkom, in to $\mathrm{v}$ letih 1667-1669 in v morejski vojni od leta 1685-1689. Poznano je tudi, da je brat tega vojvode leta 1687 obiskal Benetke in bil zelo svečano sprejet, kar tudi ni čudno, če so njegove čete $v$ tem času prelivale kri za obstoj Benetk. Istega leta je bil v Benetkah Vittorio Amedeo II in potemtakem bi ne bilo nemogoče, da je Sebenico ob tej priliki spremljal svojega gospoda in tako izvedel za tega vojvodo, ki je leta 1690 odpustil svoje francoske muzike in najel Italijane za svojo privatno kapelo. ${ }^{38}$ Nepojasnjeno pa ostane, ali je Sebenico odšel iz Turina z željo, da dobi službo v Nemčiji, in da naj bi iz tega nagiba tudi posvetil to opero ali pa je posvetilo bilo posledica neke usluge, katero bi lahko prejel iz Nemčije.

Naj bo že kakor hoče, dejstvo je, da je bil Sebenico kmalu po uprizoritvi te opere enoglasno izvoljen dne 30. junija 1692. leta kot mmaestro di capellac pri stolnici $\mathrm{v}$ mestu Cividale nel Friuli, kjer je bil že leta 1660 izvoljen za »vice-maestra« ${ }^{39}$ Poslej pa vse do svoje smrti najbrž ni menjal bivališča. Naslednjega leta 1693 so mu bili dodeljeni dohodki dveh kapel. Ker so ti dohodki vezani na pogoj, da bere vsak teden po dve maši v teh kapelah, je mogoče sklepati, da je moral postati v tem času duhovnik. Dne 20. marca leta 1695 so odločili, da Sebenica razbremene od gotovih dolžnosti, češ da je že star, kar naj bi bila hkrati tudi vaba, da ga obdržijo v mestu Cividale. Neposredno pred tem je namreč dobil ponudbo za službo $\mathrm{v}$ kraju Corbolò, ki se imenuje kot »la sua patria c. Ta odločba, da ga zadržijo, daje tudi zelo zanimivo karakteriza- 
cijo o njem kot človeku - )soggetto notorio d'una tanta virtù ed esemplarità di vita, virtuoso invidiato da non poche città (. Tri leta pozneje, 31. julija leta 1698 je bil razrešen dolžnosti poučevanja petja gregorijanskega korala. Začeli so $\mathrm{mu}$ iz leta $\mathrm{v}$ leto gledati skozi prste pri neizpolnjevanju dolžnosti in 22 . avgusta leta 1704 je dobil dopust zaradi bolezni. Dne 30. novembra 1705 je bilo objavljeno, da je po njegovi smrti njegovo mesto postalo prosto. Takoj so razpisali konkurz za njegovega naslednika in že februarja leta 1706 je bil izvoljen kot Sebenicov naslednik Pietro Romolo Pignata iz Kopra. Glede na objavljene podatke, so $\mathrm{v}$ glasbenem arhivu katedrale ( $\mathrm{ki}$ se sedaj nahaja $\mathrm{v}$ biblioteki krajevnega arheološkega muzeja ${ }^{40}$ ) tri partiture Sebenicovih kompozicij, in to en responsorium, ena maša in en motet(?). ${ }^{41}$ Kolikor mi je poznano, muzikologi teh del še niso preučevali.

Če pogledamo Sebenicovo življenje in delo pade $v$ oči dejstvo, da se nikjer niti malo ne omenja, da je objavil svoje kompozicije. Ni dvoma, da bi bile objavljene, ko bi to zaslužile, a $v$ tem primeru tudi ne bi mogle ostati docela nedotaknjene. Vse kaže, da je bil Sebenico skladatelj povprečnih kvalitet, čigar dela niso naletela na navdušen sprejem s strani publike celo $v$ času njegovega življenja. Če so naše teze o možnosti porekla skladatelja in pevca Giovannija Sebenica količkaj sprejemljive, potem stoji pred nami novo ime za zgodovino prispevkov jugoslovanskih narodov evropski glasbeni kulturi sedemnajstega stoletja. Ker pa za to razdobje ni mnogo naših imen, tudi ne bi smeli ignorirati nekega našega rojaka, pa tudi če je preživel vse svoje življenje izven svoje domovine. ${ }^{42}$

\section{OPOMBE}

${ }^{1}$ Kot je videti, se Sebenico prvič omenja v znanstveni literaturi kot Benečan $v$ delu Jeana Benjamina de Laborda, Essai de la musique ancienne et moderne, Vol. III (Paris, 1780), str. 236. Kronološko se naslednja omemba nahaja v delu Francesca Caffija, Storia della musica sacra nella capella ducale di San Marco in Venezia dal 1318 al 1797, Vol. I (Venezia, 1854), str. 314. Te informacije so potem prešle v naslednje leksikone: F. J. Fetis, Biographie universelle des musiciens, Vol. VIII (druga izdaja, Paris, 1875), str. 2, Mendel, Musikalisches Conversations Lexikon, IX (1878), str. 200 in R. Eitner, Biographisch-Bibliographisches Quellen-Lexikon, IX (Leipzig, 1903), str. 125. V svojem znatno krajšem, toda samostojnejšem delu Dizionario universale dei Musicisti, Vol. II (Milano, 1929), str. 492, Carlo Schmidl ponavlja te podatke poleg novejših posameznosti.

${ }_{2}$ Giuseppe Marioni, „La capella musicale del Duomo di Cividale, Memorie storiche Forogiuliesi, Vol. XLVII (1956-57), (Udine, 1957), str. 159.

${ }^{3}$ Ibid.

4 Dizionario Enciclopedico Italiano, Vol. III (Roma, 1956), str. 521.

5 Nuova Enciclopedia Sonzogno, Vol. I (Milano, 1953), str. 969, tudi Vol. III (1956), str. 3194 in karta teritorijev na str. 4030.

${ }^{6}$ Zgodovina narodov Jugoslavije, druga knjiga (Beograd, 1960), str. 519-521.

7 Glej dela navedena v opombi 1. Glede Legrenzija glej MGG, VIII (1960), stolpce $478 f f$.

${ }^{8}$ Procuratori di S. Marco, Chiesa, Terminazioni, reg. 146, fol. $112 \mathrm{v}$. Za to informacijo se zahvaljujem g. dr. Mariji F. Tiepolo, ki je bila tako prijazna, da je v svojem pismu $\mathrm{z}$ dne 19. X. 1961 obvestila avtorja te razprave o nekaterih doslej neznanih podatkih iz beneškega arhiva. Da je bil Sebenico tenorist $v$ katedrali sv. Marka, pričajo tudi dela, ki so navedena $v$ opombi 1. Toda izhajajoč iz tega 
podatka je Mendel v svojem leksikonu že pretvoril Sebenica v »Professor des Gesanges«.

9 Po podatkih iz neobjavljenega Caffijevega rokopisa, ki se nahaja $\mathrm{v}$ biblioteki Marciana v Benetkah (Cod. Ital. Cl. IV, n. 747, 10465, f. 286). Razen tega podatka je dr. Tiepolova sporočila, da čeprav ni poznan točen datum Sebenicovega odhoda iz Benetk, pa je vsaj znano, da so bile volitve novih tenoristov v cerkvi sv. Marka dne 26. julija 1. 1665 in 21. februarja 1.1666 (Terminazioni, fols. $124 \mathrm{v}$ in $126 \mathrm{v}$ ).

${ }^{10}$ Calendar of State Papers, Domestic Series, of the Reign of Charles II (v naslednjih opombah skrajšano kot State Papers) for 1665-1666, Vol. V (London, 1864), str. 484: beležka iz junija 1. 1666 o izplačilu mesečne plače Sebenicu in še dvema drugima glasbenikoma, $\mathrm{ki}$ so vsi vstopili $\mathrm{v}$ službo 1 . aprila tega leta.

10a State Papers, 1664-1665, Vol. IV (London, 1863), str. 273: 25. marca 1. 1665 je bil izdan potni list Vincenzu in Bartolomeju Albriciju, da potujeta »abroad ( in da se zopet vrnita. $V$ dokumentu, citiranem $v$ opombi 10 se omenjata imeni teh dveh glasbenikov s pripombo, da sta ponovno vstopila $\mathrm{v}$ službo dne 1. oktobra 1.1665 . To polletno bivanje v Evropi je vsekakor lahko nudilo priliko za potovanje v Italijo, kjer sta utegnila pripovedovati o svoji zaposlitvi, $s$ čemer bi $v$ tem primeru tudi snubila nove moči, ki bi se jima pridružile v Angliji. Dejstvo da se Sebenico in še dva muzika omenjajo $\mathrm{v}$ istem dokumentu, nas navdaja $\mathrm{z}$ mislijo, da je bila zveza med temi glasbeniki.

${ }^{11} \mathrm{Na}$ primer, State Papers, Vol. VI (London, 1864), str. 245: 7. novembra 1. 1666 je vložilo 22 muzikov prošnjo za izplačilo njihovih dohodkov, ki jih niso prejemali že več kot štiri leta in pol.

${ }^{12}$ State Papers, for Nov. 1667 - Sept. 1668, Vol. VIII (London, 1893), str. 364. O številu in razdelitvi muzikov $v$ dvorni službi glej Edward Chamberlayne, Angliae Notitia or the Present State of England, 12. izdaja (London, 1682), str. 179, kjer je navedeno 62 redno zaposlenih muzikov, ki so razdeljeni v tri skupine: Private Musick, Wind Musick and 24 violins. V prejšnjih izdajah tega dela, ki je podoben nekakšnemu imeniku dvornih uslužbencev (pregledal sem izdaje od 1669 do 1679), je navedeno samo številu muzikov, ki je vedno isto. »Italijanska kapela« je morala biti del tako imenovane »Private Musick«.

${ }^{13}$ The Diary of Samuel Pepys, ed. by H. B. Wheatley, Vol. VIII (London, 1895), str. 119. Čeprav je izdajatelj tega dnevnika domneval, da gre tu za G. B. Draghija, je že Westrup pokazal, da gre za Sebenica, glej Westrupovo monografijo o Purcellu, London, 1960, str. 96. Glej tudi Westrupov članek: „Foreign Musicians in Stuart England爪, Musical Quarterly, 27 (1941), str. 72.

${ }^{14}$ Henry Cart de Lafontaine, The King's Musick (London, 1909), str. 224, dokument datiran $\mathrm{z}$ dne 9. jul. 1670.

${ }^{15}$ State Papers, for 1670, Vol. X (London, 1895), str. 501.

${ }^{16}$ The King's Musick, str. 256.

17 State Papers, for March-October 1673, Vol. XV (London, 1902), str. 425 : Pass and Safe Conduct to Johannes Sebenico, an Italian, Master for eight [!] years of his Majesty's Italian music, who desires to return to his own country.

${ }^{18}$ Ibid., str. 540 .

19 Memoirs of Musick by the Hon. Roger North, ed. by E. F. Rimbault (London, 1846), str. 95 in 96, $\mathrm{z}$ deformiranim imenom »Sabenico(c. $\mathrm{V}$ novi izdaji tega teksta, Roger North on Music, ed. by John Wilson (London, 1959), str. 348, se Wilson sklicuje na Westrupa glede ugotavljanja identitete Sebenica. Rimbault piše v neki opombi o Sebenicu, da je ta neki italijanski glasbenik, ki je prišel v Anglijo z Marijo Este, kar pa je nemogoče, ker je ona prispela $v$ Anglijo po Sebenicovem odhodu v Turin.

${ }^{20}$ Prva omemba tega se nahaja v Rimbaultovi opombi, ki je navedena zgoraj. Lafontaine, op. cit., str. 463 in 464 prevzema to informacijo brez preverjanja. V Oxfordskem katalogu, G. E. P. Arkwright, Catalogue of Music in the Library of Christ Church, Oxford, I-II (1915-1923) ni niti enega imena, ki bi bilo blizu Sebenicovemu.

${ }^{21}$ Caffi, op. cit., Vol. II, str. 31, od koder prevzemata podatek o Cividalu Fetis in Eitner, vendar pa je videti, da Caffi ni vedel za bivanje v Turinu, ker z izjemo Schmidla ostali pisci ne omenjajo tega obdobja Sebenicovega življenja. 
${ }^{22}$ Za podatke in mikrofilme gotovih dokumentov $\mathrm{v}$ Turinu se pisec te razprave zahvaljuje direktorju Državnega arhiva v Turinu (Archivo di Stato - Torino), ki je bil tako prijazen, da je $\mathrm{v}$ dveh pismih $\mathrm{z}$ dne 19 . oktobra 1961 in $\mathrm{z}$ dne 26 . februarja 1962 dostavil iskane informacije.

${ }^{23}$ Cf. Bibliografia storica degli stati della monarchia di Savoia, urednika A. Manno in V. Promis, Vol. I. (Torino, 1884), str. 389, pod številko 5506: L'Atalanta reppresentata nel teatrino della Venaria Reale in occasione del Zappatto datto di S. A. R. a Madama Reale li 6. dicembre 1673, - In Torino 1673, per il Zapata, libraro di S. A. R., in $4^{\circ}$, stran 74. Opomba ob naslovu libreta se glasi : Musicato dal Maestro di Capella del Duca, Sebenico, in poesia del Bianco, segretario del Stato, di finanza e dei ceremoniali. Il teatro, le scene e gli apparecchi fuono eseguiti da Franco Mauro e da suo figlio Giovanni, Veneziani, architetti e macchinisti teatrali di S. A. R.

Poudariti je treba, da se ta libreto ne omenja $v$ nobeni od meni poznanih italijanskih opernih bibliografij. Vse kaže, da glasba ni ohranjena, kolikor ni založena v kakšnem arhivu v Turinu.

${ }^{24}$ Sporočil direktor Državnega arhiva $\mathrm{v}$ Turinu $\mathrm{v}$ pismu z dne 26. II. 1962.

${ }_{25}$ Archivio di Stato, Torino, Patenti Controllo di Finanze, Vol. No. 154, fol. 91 in Vol. No. 157, fol. 124 v. Sporočil direktor arhiva $v$ pismu z dne 26. II. 1962.

${ }^{26}$ Marie Jeanne Baptiste de Nemours je bila hči vojvode Charlesa Amadeusa, ki je bil ubit v dvoboju leta 1652. Leta 1665 se je poročila s Carlom Emmanuelom Savojskim, naslednjega leta pa je rodila edinega sina Vittoria Amadea II, ki je vladal od 1675 do 1732 .

${ }^{27}$ Patenti Controllo di Finanze, Vol. No. 159, fol. 203, za mikrofilm tega dokumenta se zahvaljujem direktorju arhiva v Turinu. Obrobna beležka se glasi: „Il presente ordine s'è rifatto per lire 870 solamente com' in questo à folio 218. Havendo il Sebenico ricevuto in cambi dell'anello restituito alli orefici, lire 500.(c Navedba v foliu 218 in 216 na koncu beležke kaže na potrebo preverjanja dokumentov $v$ samem arhivu, kar pa avtorju ni bilo mogoče.

${ }^{28} \mathrm{Za}$ datum tega pisma sporočilo direktorja arhiva $\mathrm{v}$ Turinu $\mathrm{v}$ pismu $\mathrm{z}$ dne 19. oktobra 1961.

${ }_{29}$ Andrea della Corte v svojem prispevku »Vita teatrale e musicale« za članek o Torinu v Enciclopedia Italiana, Vol. 34 (1937), str. 39. Francesco Cognasso v svoji Storia di Torino, tretja izdaja (Milano, 1960), str. 347, omenja znamenito )kraljevsko kapeloc in poveča zaradi tiskovne pomote število muzikov na $73(!)$.

${ }^{30}$ Knjiga Catalogo dell'archivio di musica (Torino, 1926), ki jo je uredil in izdal Andrea Della Corte, mi ni bila dostopna.

${ }^{31} \mathrm{O}$ Ivanoviću in tej operi glej moj članek $\mathrm{v}$ ZVUK $\mathrm{s}$ tam navedeno literaturo.

${ }^{32}$ Sporočil direktor arhiva $\mathrm{v}$ Turinu $\mathrm{v}$ pismu $\mathrm{z}$ dne 26. II. 1962.

${ }^{33}$ Izvedbo te opere so zabeležili: Paolo Breggi, Serie degli spettacoli rappresentati al teatro regio di Torino dal 1688 al presente (Torino, 1872), str. 5; Giacomo Sacerdote, Teatro Regio di Torino (Torino, 1892), str. 40 in Schmidl, op. cit. Glej tudi Umberto Manferrari, Dizionario universale delle opere melodrammatiche, Vol. III (Firenze, 1955), str. 275. Ime libretista ni ohranjeno. Arnaldo Bonaventura navaja v svojem delu Saggio storico sul teatro musicale italiano (Livorno, 1913), str. 158, da je bila opera izvedena leta 1687 , vendar ne navaja vira za ta podatek. Knjiga G. Robertija, La Cappella Regia di Torino, 1515-1870 (Torino, 1880) mi ni bila dostopna za preverjanje podatkov.

${ }^{34}$ Cf. Catalogo della Biblioteca del Liceo Musicale di Bologna, Vol. V: Libretti d'opera in musica, urednik Ugo Sesini (Bologna, 1943), str. 505, pod številko 5200; in O. G. T. Sonneck, Catalogue of Opera Librettos printed before 1800 in the Library of Congress, Vol. I. (Washington, 1914), str. 680

${ }^{35}$ Cf. Sesini, loc. cit., pod številko 5201. Ta libreto kakor tudi to predstavo so zabeležili tudi naslednji bibliografi: G. C. Bonlini, Le Glorie della Poesia e della Musica (Venezia, 1730), str. 119, pod številko 282; A. Groppo, Catalogo di tutti $i$ drami per musica recitati ne' Teatri di Venezia (Venezia, 1745), str. 72 pod številko 285; Drammaturgia di Lione Allacci accresciuta e continuato fino all'anno MDCCLV (Venezia 1755), stolpci 575-576. Bonlini in Allacci omenjata, da je bila ta opera predhodno izvedena $\mathrm{v}$ Turinu, vendar pa nam glede tega manjkajo arhivski podatki. 
Mimogrede povedano, navaja Allacci opero Leonida in Sparta (stolpec 481), ki je najbrž ostala nepoznana Bonliniju. Vse od Laborda pa do Manferraria so vsi leksikoni zabeležili izvedbo te opere.

${ }^{36}$ Sesini ni objavil teksta posvetila. Citirano po L. N. Galvaniju (psevdonim za G. Salviolija), I teatri musicali di Venezia nel secolo XVII (1637-1700, (Milano. 1878 ?), str. 50 .

${ }^{37}$ Cf. Allgemeine Deutsche Biognaphie, VIII (Leipzig, 1878, str. 634-635. Glej tudi Clemens Cassel, Geschichte der Stadt Celle, Bd. I. (Celle, 1930), str. 184, $190,221$.

${ }_{38}$ Cf. Dehning, Geschichte der Stadt Celle (1891).

${ }^{39}$ Ta kakor tudi vsi naslednji podatki o bivanju v Čedadu izvirajo iz članka, ki je naveden zgoraj $v$ opombi 2. Da je pisec tega članka povsem neinformiran o Sebenicovem bivanju v Angliji in Turinu pa tudi $v$ Benetkah, se vidi po tem, da ne pozna niti ene njegove opere.

40 Sporočila dr. Tiepolova iz Benetk.

${ }^{41}$ Marioni, op. cit., str. 160.

${ }^{42}$ Dr. Tiepolova me je tudi opozorila na to, da omenja Cicogna v svojem delu Iscrizioni veneziane, Vol. II (Venezia, 1827), str. 151, nagrobni napis za nekega Gio. Sebenica in njegove naslednike. Napis naj bi se nahajal blizu cerkve Sv. Zaccarija. $\mathrm{Na}$ žalost to delo avtorju ni bilo dostopno, da bi preveril ta podatek kakor tudi eventualno leto tega napisa.

Poseben podatek $k$ tej študiji z namenom podkrepiti možnosti, da je Sebenico izviral iz rodbine, ki je bila najbrž po poreklu iz Sibenika, predstavlja tudi primer Ivana Lukačića, ki si je leta 1615 pridobil v Rimu naslov »Magister Musicae in ki je ob tej priliki naveden kot Joannes de Sibinico. Cf. prikaz Plamenčeve izdaje Lukačićevih del v Note d'archivio per la storia musicale, Vol. XIV (1937), str. 319. Tudi citirano v članku »Musicisti dell'ordine Francescano dei Minori Conventuali( tudi v Note d'archivio Vol. XVI (1939), str. 190. Da vem, da gre v tem primeru za Lukačića, se moram zahvaliti dr. Draganu Plamencu, ki je bil tako prijazen, da me je opozoril na ta podatek.

\section{SUMMARY}

According to existing documentation, Sebenico was born in Carbolo (i. e. Carbolone) in the territory of the Venetian Republic. However, considering the fact that artists at this time often took the name of their birth place, it is possible that the composer was a native of Sibenik (Sebenico) in Dalmatia, and that his family may have fled before the Turks to Italy, while he was still a child.

Sebenico was probably a pupil of Legrenzi. In the year 1660 he became the »vice-maestro" of the cathedral in Cividale nel Friuli, and in 1663 was accepted as a tenor in the chapel of St. Mark's in Venice. From 1660 until 1673, Sebenico acted as chapel master and chorister at the English court in London. On the basis of newly discovered material we know that immediately upon his return to Italy in 1673 he took the post of maestro di cappella at the court of Savoy in Turin; in the same year his opera »L'Atlanta» was performed there. Of Sebenico's further activities as a composer we have no more information until the year 1689 when his opera "Leonida in Sparta ( was given in Venice. In 1692 his opera »L'opresso solevato( was produced, also in Venice. In the same year, he left Turin and became maestro di cappella in the cathedral in Cividale nel Friuli where he remained until his death in 1705 .

The music of Sebenico's above-mentioned operas has apparently not survived, but we know that three of his church compositions are to be found in the archives of the cathedral of Cividale nel Friuli; their value is as yet not established. The fact, however, that Sebenico's compositions were never published would seem to indicate that he was a composer of only mediocre quality. 